\title{
THE DETERMINANT FACTORS OF BEHAVIOR IN M-COMMERCE APPLICATION USAGE FOR ONLINE PURCHASING
}

\author{
Wisnu Putra Prihantoro*), Arif Satria ${ }^{* *}$, and Hartoyo $\left.{ }^{* * *}\right)$ \\ *) IICS School \\ Jl. Batu Mulia Blok K, Meruya Utara, Kembangan, Jakarta Barat 11620 \\ **) Department of Communication Science and Community Development, Faculty of Human Ecology, \\ Bogor Agricultural University \\ IPB Darmaga Campus, Bogor 16680 \\ ${ }^{* * *}$ School of Business, Bogor Agricultural University \\ Jl. Pajajaran, Bogor 16151
}

\begin{abstract}
The development of technology in human life makes the process of buying and selling currently using the online system. The high electronic transactions that occur in Indonesia are driven by the number of e-commerce or companies that make m-commerce applications on smartphones. This research has several objectives, and the first goal is to know the effect of perceived usefulness, behavior of the use of m-commerce applications, subjective norms, and behavioral control of interest in $\mathrm{m}$-commerce applications on smartphones on online purchases. The second goal is to analyze the ease of use of perceived usefulness, and the third objective is to analyze the effect of ease of use and perceived usefulness on the behavior of using $\mathrm{m}$-commerce applications for online purchases. The fourth objective is to analyze the effect of security perception on the interest of using $\mathrm{m}$-commerce application on online purchase. This research was conducted by survey method and using SEM for data analysis. The results of this research indicate that there are significant influences among the behavior of the use of $\mathrm{m}$-commerce applications, perceived usefulness, and behavioral control over interest in using $\mathrm{m}$-commerce applications for online purchases. Ease of use and usability positively affect the behavior of using m-commerce applications. Ease of use positively affects the perceived usefulness. The security factor has a positive effect on the interest of using $\mathrm{m}$-commerce application.
\end{abstract}

Keywords: e-commerce, m-commerce adoption, SEM, Technology Acceptance Model, Theory of Planned Behavior

Abstrak: Perkembangan teknologi dalam hidup manusia membuat proses jual beli saat ini berlangsung dengan sistem online. Tingginya transaksi elektronik yang terjadi di Indonesia didorong dengan banyaknya e-commerce atau perusahaan yang membuat aplikasi m-commerce di smartphone. Penelitian ini memiliki beberapa tujuan, tujuan yang pertama yaitu untuk mengetahui mengetahui pengaruh kegunaan yang dirasakan, sikap penggunaan aplikasi m-commerce, norma subjektif, dan kontrol perilaku terhadap minat menggunakan aplikasi m-commerce di smartphone untuk pembelian online. Tujuan kedua yaitu menganalisis kemudahan penggunaan terhadap kegunaan yang dirasakan. Tujuan yang ketiga yaitu menganalisis pengaruh kemudahan penggunaan dan kegunaan yang dirasakan terhadap sikap penggunaan aplikasi m-commerce untuk pembelian online. Tujuan yang keempat yaitu menganalisis pengaruh persepsi keamanan terhadap minat penggunaan aplikasi m-commerce untuk pembelian online. Penelitian ini dilakukan dengan metode survei dan menggunakan SEM untuk analisis data. Hasil dari penelitian ini menunjukkan bahwa ada pengaruh signifikan antara sikap penggunaan aplikasi m-commerce, kegunaan yang dirasakan, kontrol perilaku terhadap minat menggunakan aplikasi m-commerce untuk pembelian online. Kemudahan dalam penggunaan dan kegunaan berpengaruh positif terhadap sikap penggunaan aplikasi m-commerce. Kemudahan penggunaan berpengaruh positifterhadap kegunaan yang dirasakan. Faktor keamanan berpengaruh positif terhadap minat penggunaan aplikasi m-commerce.

Kata kunci: adopsi m-commerce, e-commerce, SEM, Technology Acceptance Model, Theory of Planned Behavior

\footnotetext{
${ }^{1}$ Corresponding author:

Email: wisnuputrap@gmail.com
} 


\section{INTRODUCTION}

The development of information technology (IT) and information and communication technology (ICT) affect all aspects of life. Humans today are very dependent on the internet to support their activities. Survey conducted by the Association of Internet Network Providers Indonesia (APJII) found that $51.8 \%$ of Indonesia's population of 132.7 million people has been connected to the internet. $63.5 \%$ or 84.2 million people have performed online transactions and online shopping. Among 132.7 million internet users in Indonesia, 47.6\% or about 63.1 million people access the internet by using mobile devices or smartphones (APJII, 2016).

The development of online business or commonly referred to as e-commerce has grown rapidly in Indonesia. Kotler \& Keller (2007) define e-commerce as process of selling and buying supported by electronic devices. The development of e-commerce brought changes marked by changes in business activities running in the physical world and then developed into the virtual world. According to data released by the MoCI (2016), the value of e-commerce transactions in Indonesia continues to increase since 2014 i.e. USD 12 billion to USD 18-19 billion in 2015, and is estimated to be USD 25 billion in 2016 .

The rising phenomenon of online purchasing makes retail stores encounter decreasing profits and causes them out of business. The visitors in one of the shopping centers like Roxi, Glodok have decreased. In 2017, several clothing stores including Sun, Lotus, and Dabenhams closed some of their outlets. Online purchasing starts to become the consumer's choice rather than having to go to the store and spend their time on their way. Javadi et al. (2012) state that online shop consumers can benefit from convenient shopping and the certainty level of the products they need. Current online purchasing is not restricted merely for merchandise, yet they have already expanded to service. Travel ticketing and hotel booking services have been made online. In addition, the millennial, the dominant consumers in Indonesia, are getting more lavish in spending money for the experience needs such as recreation, dining out, and etc. (Yuswohady, 2017). Consumers' desire for recreation encourage them to utilize e-commerce to do online ticket purchasing and online hotel booking.

Nowadays, e-commerce companies are starting to see opportunities to make their sites into the form of applications on smartphones that are more easily accessible by users. E-commerce applications on this smartphone can be called as mobile-commerce or m-commerce. E-commerce in Indonesia began to intensify to create $\mathrm{m}$-commerce applications that can be accessed from smartphones and make promotions for consumers to use them. Mobile-commerce can be seen as a further development of e-commerce (Wakefield and Whitten, 2006). Chaffey (2007) defines m-commerce as a transaction and electronic communication that occur using mobile devices such as laptops, PDAs, cell phones or smartphones that use wireless or wireless connections. It can be concluded that m-commerce is the use of mobile devices to sell and buy products, services, or access information wherever and whenever using the internet network.

The growing phenomenon of online purchases makes e-commerce appear and make m-commerce applications a place for consumers to buy their various needs. Tight competition between m-commerce applications, if not anticipated by each company with a good strategy, will potentially cost them to lose. Every m-commerce application created by the company is expected to know the characteristics of consumers who make online purchases using $\mathrm{m}$-commerce applications. In addition, each company needs to know the factors influencing the interest in using $\mathrm{m}$-commerce applications to make online purchases. Thus, the company can formulate the right strategy to face business competition.

The number of previous studies on factors influencing the interest in using $\mathrm{m}$-commerce applications for online purchases in Indonesia is still relatively small. Some researches on m-commerce applications conducted by the researchers from other countries are as follow: Gupta (2017) who conducted research on m-commerce adoption using variables in model Technology Acceptance Model (TAM) in India; Raeisi and Lingjie (2016) who conducted a study of m-commerce adoption in China by using a combination of TAM and TPB models added with an innovation adoption factor. Bhatti (2007) conducted a study using TAM and TPB models in added with personal innovativeness variables. Some of these studies are more focused on m-commerce applications for financial services/banking, while this research highlights the m-commerce for goods and services transactions. In addition, this study also adds an influential security perception variable in online transactions. 
The use of m-commerce applications in smartphone is one of technology adoption behaviors to make purchasing transaction. Consumers will feel confident to use an m-commerce app if they feel the technology is easy to use, useful and security guaranteed. Purchase behavior by using m-commerce applications on smartphones is preceded by an interest in using the app. According to TPB planned behavioral theory, interest in behavior is influenced by attitude toward behavior, subjective norms and control over perceived behavior.

Objectives to be achieved from the research implementation is to examine the relationship patterns between the influence of perceived usefulness and the behavior of the use of m-commerce applications, subjective norms, and behavioral control of interest in using m-commerce applications in smartphones for online purchases. The second goal is to analyze the ease of use on the perceived usefulness. The third purpose is to analyze the effect of ease of use and perceived usefulness on the behavior of the use of m-commerce applications for online purchases. The fourth objective is to analyze the effect of security perception on the interest of using m-commerce application for online purchase.

The limitation of this research is to examine the interest rate in continuing to use m-commerce applications for online purchases by using a combination of TAM and TPB theories. However, this research did not add external variables on TAM, as conducted by Yaghoubi and Shakeri (2010). On the other hand, it eliminated the correlations between each variable i.e. behavior, subjective norm, and behavioral control on TPB, as conducted by Fusilier (2005).

\section{METHODS}

This research used quantitative data to obtain primary data by conducting surveys and using questionnaires on the related to user behavior of $\mathrm{m}$-commerce application usage on smartphone. The secondary data were obtained from literature studies, scientific journals, and previous research results relevant to the object or problems being examined.

Data were obtained from online questionnaire distribution with the help of questionnaire tools provided by Google Doc. The Google doc link was deployed via chatting group i.e. WhatsApp, an instant messaging application. This research had unknown number of population and the sampling size was not possible to be determined by mathematical formula. In multivariate analysis, the sample size was suggested to be 10 times or more than the research's variable number (Sekaran, 2011). Determination of sample size was based on Hair et al. (1995) i.e. the number of samples was 5-10 timed the number of indicators, and added the number of latent variables. The numbers of samples of this research were 200 people taken by purposive sampling technique, with some specific considerations. The consideration is that respondents have used $\mathrm{m}$-commerce applications to make online purchases. The number of received data reached up to 200 data, and the number of analyzed data was also 200 .

The analytical method used was Structural Equation Modeling (SEM). SEM analysis is used in searching for causal relationships that can measure relationships that are unable to be measured directly or so-called latent variables. Measuring them requires an approach through measurement of other influencing factors and can be measured or called as the indicator variable. The causality relationship is depicted in a path diagram to show the flow of relations between endogenous and exogenous variables. The development of the path diagram in the research determines the effect of perceived usefulness, perceived ease of use, perceived behavioral control, subjective norm, and behavior of m-commerce application usage, the perception of security on behavioral intention in using m-commerce applications for online purchases. The variables used in this research were 7 latent variables ( 3 endogenous and 4 exogenous latent variables). Table 1 exemplifies the latent variables and their indicators in the research model.

Advances in information technology enable buying and selling transactions to be conducted electronically by using e-commerce. The increasingly widespread use of smartphones makes e-commerce companies create $\mathrm{m}$-commerce applications to conduct transactions on smartphones. Interest variables by using $\mathrm{m}$-commerce applications according to TAM theory are perceived usefulness, ease of use, and behavior of m-commerce application usage. Interest variables using $\mathrm{m}$-commerce applications, according to TPB theory, are the behavior of application usage, subjective norm, and behavior control. The advantage of this research is to combine TAM and TPB models to examine the respondents' behavior in adopting $\mathrm{m}$-commerce technology and adds 
security variable as a significant variable that will show the level of the respondent's degree of trust towards $\mathrm{m}$-commerce application. Figure 1 is the framework of this research.
Behavioral intention in using $\mathrm{m}$-commerce applications to make purchases is explained through hypotheses. The hypothesis proposed in this study as a temporary answer to the structural model is as follows:

Table 1. Variables of operational definitions

\begin{tabular}{|c|c|c|c|}
\hline Variable & Variable definition & Description & Symbol \\
\hline \multicolumn{4}{|c|}{ Exogenous latent variable } \\
\hline \multirow{5}{*}{$\begin{array}{l}\text { Perceived } \\
\text { Ease of Use } \\
(\mathrm{X} 1)\end{array}$} & \multirow{5}{*}{$\begin{array}{l}\text { The ease of use is defined } \\
\text { as level of belief in using } \\
\text { particular system in which } \\
\text { the usage is effortless (Davis, } \\
\text { 1989). }\end{array}$} & M-commerce application is easy to be installed & $\mathrm{X} 11$ \\
\hline & & Features are easy to use & $\mathrm{X} 12$ \\
\hline & & Purchasing transactions are easy to do & $\mathrm{X} 13$ \\
\hline & & Payment process is convenient & $\mathrm{X} 14$ \\
\hline & & Easily accessible m-commerce applications & $\mathrm{X} 15$ \\
\hline \multirow{4}{*}{$\begin{array}{l}\text { Subjective } \\
\text { Norm (X2) }\end{array}$} & \multirow{4}{*}{$\begin{array}{l}\text { Subjective Norms are defined } \\
\text { as individual or group } \\
\text { references to agree or reject } \\
\text { certain behavior (Peterson, } \\
\text { 2012). }\end{array}$} & People around me use m-commerce application & $\mathrm{X} 21$ \\
\hline & & My surroundings suggest me to use m-commerce application & $\mathrm{X} 22$ \\
\hline & & My close friends agree that & $\mathrm{X} 24$ \\
\hline & & Endorsers/celebrities use m-commerce application & $\mathrm{X} 25$ \\
\hline \multirow{3}{*}{$\begin{array}{l}\text { Behavioral } \\
\text { Control (X3) }\end{array}$} & \multirow{3}{*}{$\begin{array}{l}\text { Behavioral control can be } \\
\text { defined as people's perception } \\
\text { on their capability to perform } \\
\text { certain behavior (Safeena et al. } \\
\text { 2013). }\end{array}$} & I have the knowledge and capability & $\mathrm{X} 31$ \\
\hline & & I do not need guidance from anyone & $\mathrm{X} 32$ \\
\hline & & I am capable of finishing the purchase transaction & X33 \\
\hline \multirow{5}{*}{$\begin{array}{l}\text { Security } \\
\text { Perception } \\
\text { (X4) }\end{array}$} & \multirow{5}{*}{$\begin{array}{l}\text { According to Park and Kim } \\
\text { (2006), security is defined } \\
\text { as online shop capacity in } \\
\text { monitoring and securing data } \\
\text { transaction }\end{array}$} & It is secured to give personal data & $\mathrm{X} 41$ \\
\hline & & Personal information will not be published & $\mathrm{X} 42$ \\
\hline & & M-commerce application has information security mechanism & $\mathrm{X} 43$ \\
\hline & & There is no financial risk & $\mathrm{X} 44$ \\
\hline & & My money is fully refunded if the transaction is failed & $\mathrm{X} 45$ \\
\hline \multicolumn{4}{|c|}{ Endogenous latent variable } \\
\hline \multirow{5}{*}{$\begin{array}{l}\text { Perceived } \\
\text { Usefulness } \\
\text { (Y1) }\end{array}$} & \multirow{5}{*}{$\begin{array}{l}\text { Davis (1989) states that } \\
\text { perceived usefulness is defined } \\
\text { as individual trust level in } \\
\text { using particular system in } \\
\text { supporting their performance. }\end{array}$} & Saving time in shopping & Y11 \\
\hline & & Helping to buy travel and accommodation ticket & $\mathrm{Y} 12$ \\
\hline & & Helping to see variations of goods and price & Y13 \\
\hline & & Helping to pay bills & Y14 \\
\hline & & Helping to sell secondhand goods and my production goods & Y15 \\
\hline \multirow{5}{*}{$\begin{array}{l}\text { The behavior } \\
\text { of using } \\
\text { M-Commerce } \\
\text { application } \\
\text { (Y2) }\end{array}$} & \multirow{5}{*}{$\begin{array}{l}\text { The behavior of m-commerce } \\
\text { application usage is a belief } \\
\text { that every behavior of using } \\
\text { m-commerce application will } \\
\text { result in certain outcomes } \\
\text { (Aizen and Fishbein, 1991). }\end{array}$} & M-commerce application makes me more productive & Y21 \\
\hline & & $\begin{array}{l}\text { M-commerce application speeds up the travel and } \\
\text { accommodation ticket purchasing }\end{array}$ & $\mathrm{Y} 22$ \\
\hline & & The m-commerce application is safe & Y23 \\
\hline & & I receive goods exactly like the picture & Y24 \\
\hline & & Profitable transaction as it is cheaper and has many discounts & Y25 \\
\hline \multirow{2}{*}{$\begin{array}{l}\text { The interest } \\
\text { of using } \\
\text { m-commerce } \\
\text { application } \\
\text { (Y3) }\end{array}$} & \multirow{2}{*}{$\begin{array}{l}\text { According to Jogiyanto (2007), } \\
\text { In the interest rate in conscious } \\
\text { sense, they consider available } \\
\text { information, and implicitly and } \\
\text { explicitly consider implications } \\
\text { of the actions. }\end{array}$} & $\begin{array}{l}\text { Have an interest in using } \mathrm{m} \text {-commerce to purchase travel } \\
\text { ticket and hotel booking }\end{array}$ & Y31 \\
\hline & & $\begin{array}{l}\text { Have an interest in doing re-purchasing that I need or paying } \\
\text { bills regularly }\end{array}$ & Y32 \\
\hline
\end{tabular}




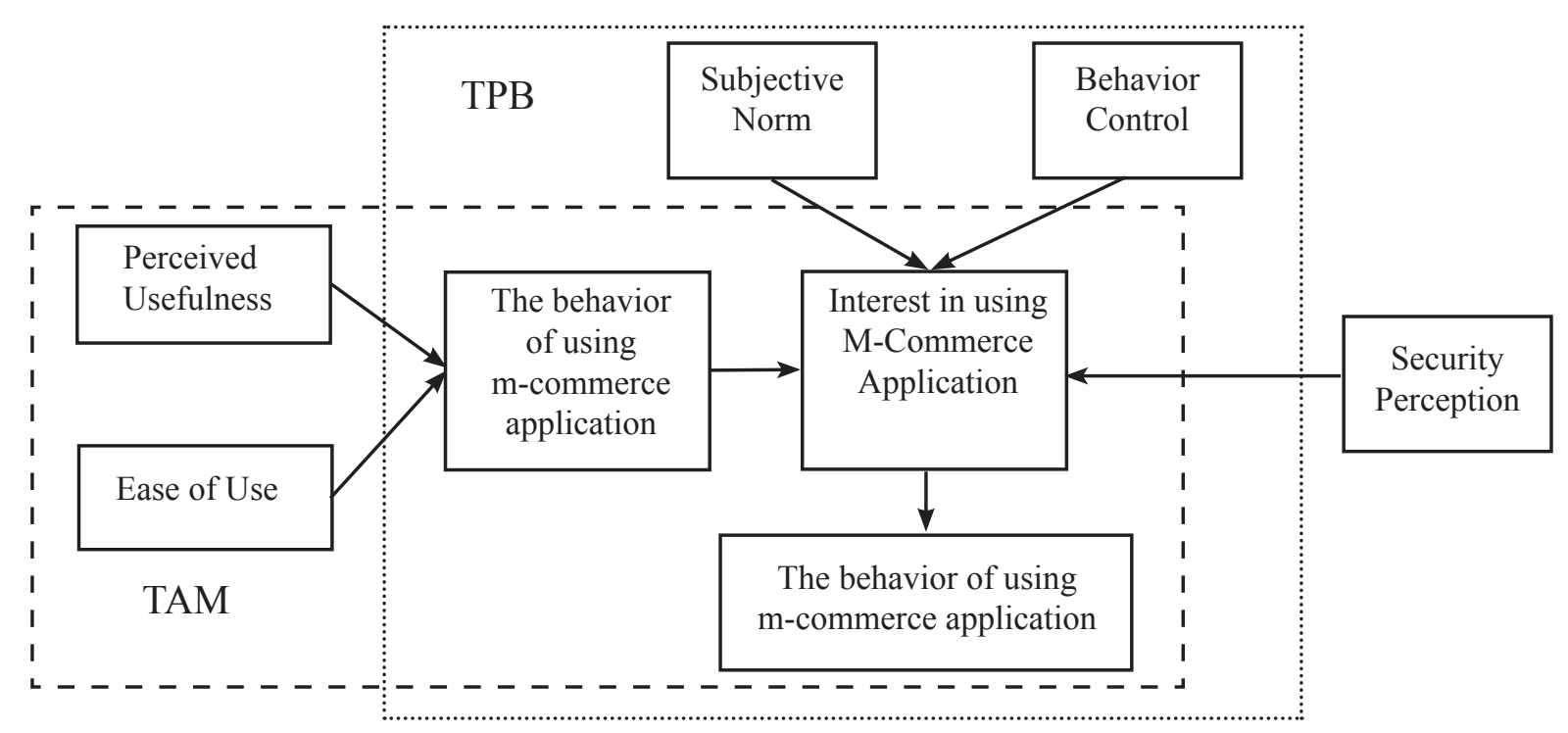

Figure 1. Research framework

1. The effect of perceived usefulness on behavioral intention

According to Davis (1989), Perceived Usefulness can be defined as the level of confidence of a person in using a particular system in support of its performance. According to Venkatesh and Davis (2000) perceived usefulness is the most dominant factor in determining behavioral intention. Thus it can be hypothesized, H1: Perceived usefulness positively affects the interest of using $\mathrm{m}$-commerce applications for online purchases.

2. The influence of behavior toward behavior on behavioral intention

Behavior shows what consumers like and dislike (Engel et al. 1995). A person shapes behavior based on the beliefs on behavior by relating it to the consequences or outcomes of the behavior. Researchers conducted by Raeisi and Meng (2016), Celik and Yilmaz (2011), Safeena et al. (2013), Yaghoubi and Bahmani (2010) show that behavior toward behavior has a positive and significant effect on intention. Therefore, it can be hypothesized as follows, H2: The use of m-commerce applications positively affects the interest in using $\mathrm{m}$-commerce for online purchases.

3. The influence of subjective norms on behavioral intention.

The subjective norm also refers to individual or group references to approve or refuse behavior (Peterson 2012). Research conducted by Bhatti (2007), Safeena et al. (2013) and Rhodes et al. (2006) suggest that subjective norms have a positive effect on interest. H3: The subjective norm positively affects the interest in using $\mathrm{m}$-commerce applications for online purchases.

4. The influence of perceived behavioral control on behavioral intention

Perceived Behavioral Control can be defined as people's perception of their ability to perform certain behaviors (Safeena, 2013). Results of research conducted by Raeisi and Meng (2016), Bhatti (2007), Safeena et al. (2013), Quan et al. (2010), Yaghoubi and Bahmani (2010) proved empirically that, behavior control has a positive effect on interest. Thus, the hypothesis can be put forward as follows, H4: Behavioral control positively affects the interest of using m-commerce applications for online purchases.

5. The influence of security perceptions on behavioral intention

According to Park and Kim (2006), security or security is defined as the ability of online stores in conducting surveillance and security of data transactions. According to research by Saleh and Mashhour (2014), Alwafi and Magnadi (2016), Aineah (2016), the perception of security positively affects the interest of using online purchases. Referring to the above description, research hypothesis is planned as follow, H5: Security positively affects the interest of using $\mathrm{m}$-commerce applications for online purchases. 
6. The influence of ease of use on perceived usefulness.

Perceived Ease of Use is defined as the degree of confidence in the use of a particular system which in its use does not require strong effort (Davis, 1989). The results of Yaghoubi and Bahmani (2010), Celik and Yilmaz (2011), Gupta (2017) showed that ease of use had an effect on the system utilization. Thus, it can be hypothesized as follow, H6: Ease of use positively affects the perceived usefulness of m-commerce applications for online purchases.

7. The influence of ease of use on behavior toward behavior

Perceived Ease of Use is defined as the degree of trust in the use of a particular system which in its use does not require strong effort (Davis, 1989). The results of Yaghoubi and Bahmani (2010), Celik and Yilmaz (2011) showed that ease of use had an effect on behavior toward the system. Thus, it can be hypothesized, H7: Ease of use positively affects the behavior of using $\mathrm{m}$-commerce applications for online purchases.

8. The influence of perceived usefulness on behavior toward behavior toward behavior

According to Davis (1989), perceived usefulness can be defined as the level of trust in using a particular system in support of its performance. Research conducted by Gupta (2017), Celik and Yilmaz (2011) show that the perception of usefulness as a positive effect on the behavior of the use of information systems. Thus, it can be hypothesized, H8: The perceived usefulness positively affects the behavior of using m-commerce applications for online purchases

All dimensions and indicators presented in Table 1 are linked to serve as a path diagram model showing the flow of relations between endogenous and exogenous variables 2 (Figure 2).

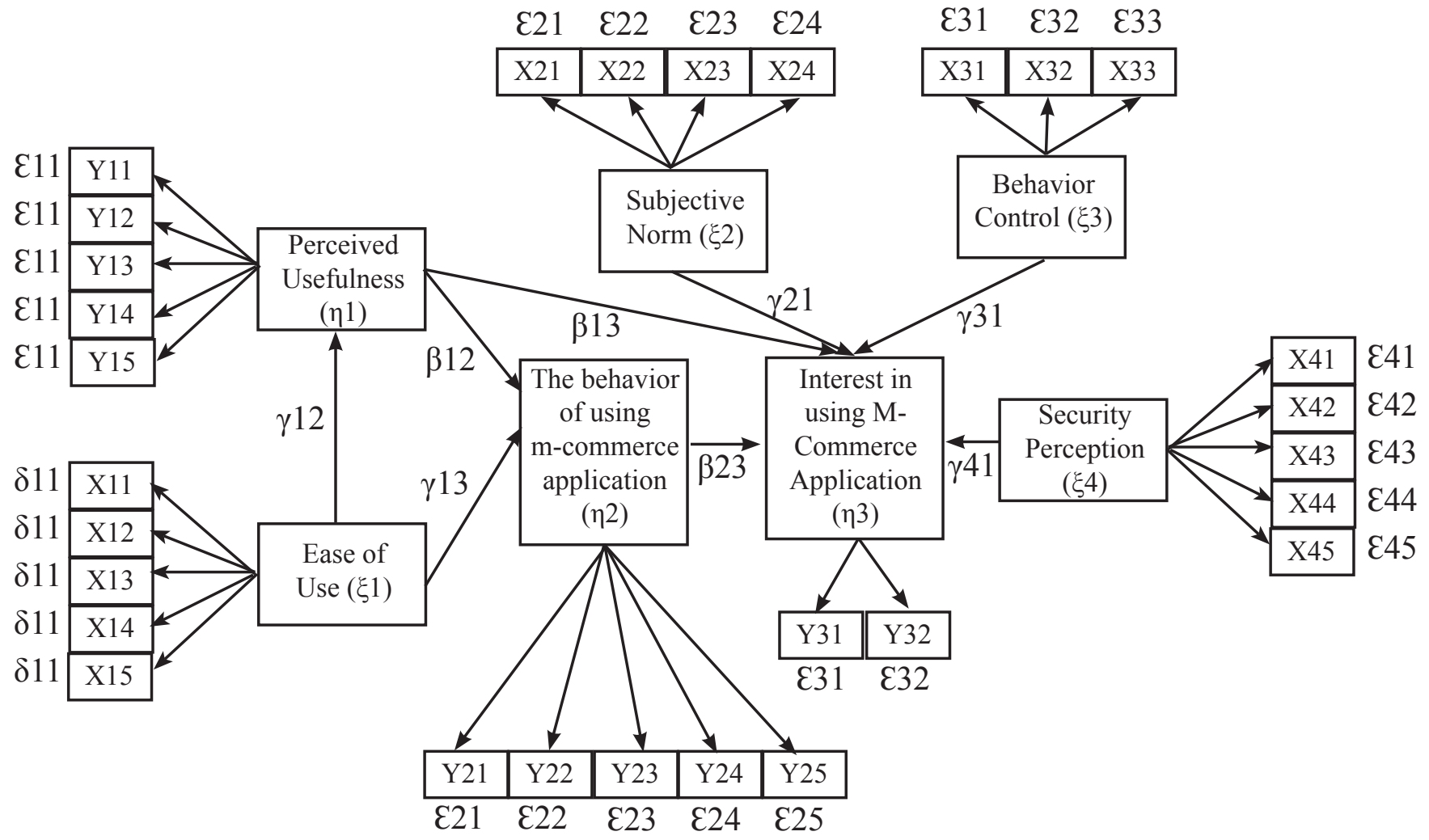

Figure 2. SEM Model of behavioral intention in using m-commerce application 


\section{RESULTS}

\section{Demographic Characteristics of Respondents}

Demographic characteristics are identified to examine the characteristic of $\mathrm{m}$-commerce application users observed based on certain characteristics. The demographic characteristics of m-commerce app users are essential to examine their buying behavior; therefore, marketers can adjust matching products or services. Demographic characteristics can be seen in Table 2.

\section{The Behavior in Using M-commerce Application}

The primary reasons why the majority of the respondents conduct online purchasing by using m-commerce application are due to the easy accessibility, reasonable price, and discounts. The most frequently used m-commerce applications are Tokopedia, Shopee, and Traveloka. Most of them stated that the most frequently bought goods include clothing and fashion, travel tickets, hotels, and cellphone accessories.

\section{Evaluation of Model Fit Level}

According to Hair et al. (1995), fit assessment is conducted through several stages i.e. 1) overall model fit; 2) suitability of measurement model; 3) suitability of the structural model. Based on an overall model fit assessment, this model was already qualified and good fit so that the research model became feasible. Measurement of this model was tested with validity and reliability tests. The results of validity and reliability test show that the model has fulfilled the requirement indicated by Variance Extracted (VE) $>0.5$ which means that the model is valid, and the value of Construct Reliability $(\mathrm{CR})>0.7$, which means that each latent construct is valid and reliable. Referring to the structural suitability test, the hypothesis is considered to be acceptable. The SEM model can be seen in Figure 3.
Table 2. Respondents' demographic characteristics

\begin{tabular}{|c|c|}
\hline Characteristic & $\begin{array}{c}\text { M-commerce } \\
\text { application user (\%) }\end{array}$ \\
\hline \multicolumn{2}{|l|}{ Gender } \\
\hline Male & 40 \\
\hline Female & 60 \\
\hline \multicolumn{2}{|l|}{ Age } \\
\hline$<20$ years old & 7 \\
\hline 21-30 years old & 53 \\
\hline $31-40$ years old & 30 \\
\hline $41-50$ years old & 8 \\
\hline$>51$ years old & 2 \\
\hline \multicolumn{2}{|l|}{ Occupation } \\
\hline Student & 7 \\
\hline College Student & 8 \\
\hline Employee & 73 \\
\hline Enterpreneur & 9 \\
\hline Housewife & 3 \\
\hline \multicolumn{2}{|l|}{ Education } \\
\hline Senior High School (SMA) & 11 \\
\hline Vocational Program (Diploma) IPB & 4 \\
\hline Undergraduate (S1) & 70 \\
\hline Postgraduate (S2) & 15 \\
\hline S3 & 0 \\
\hline \multicolumn{2}{|l|}{ Monthly Expense } \\
\hline$<$ Rp1.000.000,- & 8 \\
\hline Rp1.000.001 - Rp3.000.000,- & 21 \\
\hline Rp3.000.001 - Rp5.000.000,- & 33 \\
\hline Rp5.000.001 - Rp7.000.000,- & 21 \\
\hline$>$ Rp7.000.000,- & 17 \\
\hline
\end{tabular}

The total of Applications displayed in the smartphone

$\begin{array}{ll}1 \text { application } & 18 \\ <3 \text { applications } & 31 \\ 3-5 \text { applications } & 42 \\ 5-7 \text { applications } & 7 \\ >7 \text { applications } & 2\end{array}$

Number of Online Purchasings in the last three months

\begin{tabular}{ll} 
Never & 6 \\
$1-3$ times & 43 \\
$4-6$ times & 35 \\
$7-9$ times & 6 \\
$>9$ times & 10 \\
\hline
\end{tabular}




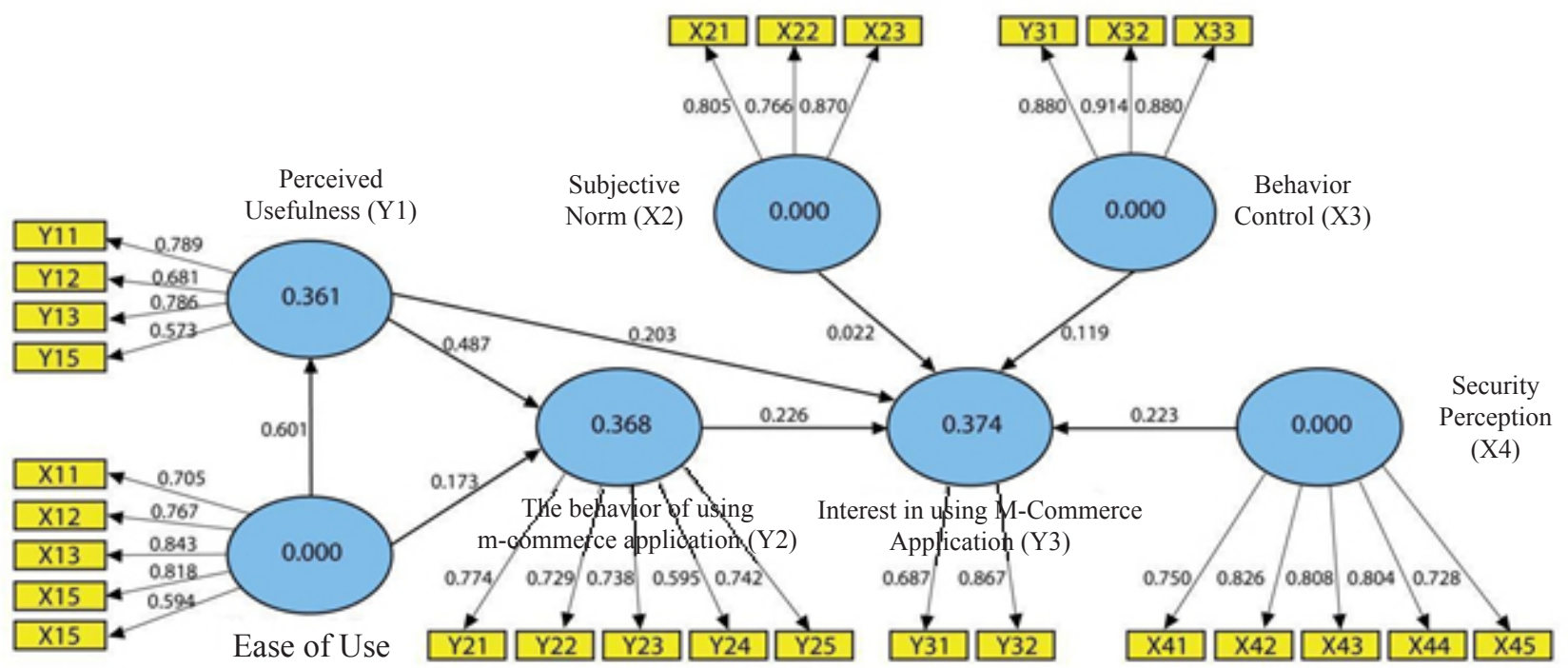

(X1)

Figure 3. Final Measurement Model

\section{Measurement Model: Shaping Indicators of Latent Variables}

There were 7 latent variables discussed in this research i.e. subjective norm, behavior control, use attitude, security perception, usability, ease and interest. The indicator with the highest contribution to explain the subjective norm is X23 (The person closest to me agreed if I use m-commerce to make a purchase), indicating that the people around the respondents have an influence in deciding to make online purchases using $\mathrm{m}$-commerce applications. Meanwhile, the indicator with the highest contribution to explain the behavior control is X32 (I do not need anyone's guidance to learn to use $\mathrm{m}$-commerce applications on smartphones) showing that respondents have the ability and do not need to be guided by others when using $\mathrm{m}$-commerce applications.

The indicator with the highest contribution to explain the security perception is X42 (m-commerce applications will not provide my personal information to others without my consent) explaining that respondents have often used m-commerce applications for online purchases and believe that the security level of the application to keep the secrets of consumer data has been very good. The highest contribute indicator to explain the ease of use is X13 (Easily make any ticket purchase transaction, hotel, or any item I want with m-commerce application on smartphone) explaining that m-commerce application makes it easy for the respondents to buy tickets, hotels and any items that they need.
The highest contributing indicator for the use of $\mathrm{m}$-commerce applications is Y21 (I'm convinced that using m-commerce apps on smartphones makes me more productive as I do not need to spend time buying in the store) indicating that respondents are assured that conducting online purchasing allow them to have more productive life as they can do much more than going to the store to buy an item. The indicator with the highest contribution to perceived usefulness is Y11 (m-commerce app on smartphone is useful to save time when shopping than if I go to store) showing that $\mathrm{m}$-commerce application is useful to save time when shopping can be done at home and elsewhere.

The highest contributing indicator for behavioral intention in using m-commerce apps for online purchases is Y32 (I will use m-commerce apps regularly (often) in the future to make item purchases I need or for arranging bill payments) exemplifying that respondents will continue to be interested in using $\mathrm{m}$-commerce applications to make online item purchases they need.

\section{Structural Model: Variables Influencing the Rate of Behavioral Intention in Using M-Commerce Application}

The result of hypothesis testing shows that almost all factors influence the interest in using m-commerce application. Nonetheless, there is one factor, i.e. subjective norm, which has no positive effect on interest in using m-commerce application. The hypothesis testing can be seen in Table 2 . 


\begin{tabular}{lccccc}
\hline \multicolumn{1}{c}{ Variable } & Loading Factor & T count & Conclusion & R-square \\
\hline $\begin{array}{l}\text { H1: Perceived Usefulness } \rightarrow \text { Behavioral intention in } \\
\text { using m-commerce applications }\end{array}$ & 0.203 & 4.03 & Significant & $\begin{array}{l}\text { Hypothesis } \\
\text { is accepted }\end{array}$ & 0.374 \\
$\begin{array}{l}\text { H2: Behavior of m-commerce application usage } \rightarrow \\
\text { Behavioral intention in using m-commerce applications }\end{array}$ & 0.226 & 4.53 & Significant & $\begin{array}{c}\text { Hypothesis } \\
\text { is accepted }\end{array}$ \\
$\begin{array}{l}\text { H3: Subjective Norms } \rightarrow \text { Behavioral intention in using } \\
\text { m-commerce applications }\end{array}$ & 0.022 & 0.74 & $\begin{array}{c}\text { Not } \\
\text { Significant }\end{array}$ & $\begin{array}{c}\text { Hypothesis } \\
\text { denied }\end{array}$ \\
$\begin{array}{l}\text { H4: Behavioral Control } \rightarrow \text { Behavioral intention in } \\
\text { using m-commerce applications }\end{array}$ & 0.119 & 2.16 & Significant & $\begin{array}{l}\text { Hypothesis } \\
\text { is accepted }\end{array}$ \\
$\begin{array}{l}\text { H5: Security Perception } \rightarrow \text { Behavioral intention in } \\
\text { using m-commerce applications }\end{array}$ & 0.223 & 4.98 & Significant & $\begin{array}{l}\text { Hypothesis } \\
\text { is accepted }\end{array}$ \\
H6: Ease of Use $\rightarrow$ Perceived Usefulness & 0.601 & 18.90 & Significant & $\begin{array}{l}\text { Hypothesis } \\
\text { is accepted }\end{array}$ & 0.361 \\
$\begin{array}{l}\text { H7: Ease of Use } \rightarrow \text { Behavior of m-commerce } \\
\text { application usage }\end{array}$ & 0.173 & 3.98 & Significant & $\begin{array}{l}\text { Hypothesis } \\
\text { is accepted }\end{array}$ & 0.368 \\
$\begin{array}{l}\text { H8: Perceived Usefulness } \rightarrow \text { Behavior of m-commerce } \\
\text { application usage }\end{array}$ & 0.487 & 12.93 & Significant & $\begin{array}{l}\text { Hypothesis } \\
\text { is accepted }\end{array}$ & \\
\hline
\end{tabular}

The Relationship Patterns of Perceived Usefulness, the Use of M-commerce Applications, Subjective Norms, and Behavioral Control on Behavioral Intention in M-commerce Applications on Smartphones for Online Purchases.

The result of t-count in Table 2 shows that hypothesis 1 (H1) is accepted i.e. the usefulness of m-commerce application perceived by the users positively influences the behavioral intention in using it with the t-value of $4.03>1.967$. The findings are consistent with those found by Gupta (2017), Yaseen and Zayeed (2010) stating that if users feel the m-commerce app is useful to them, there would be positive behavioral intention in using the application. Based on the data results in Table 2, the behavior factor of the m-commerce application usage positively influences one's interest in using m-commerce application for online purchase with the t-value of $4.53>1.967$. This highlights that hypothesis $2(\mathrm{H} 2)$ is accepted, that is the behavior of $\mathrm{m}$-commerce application usage has a positive effect on the interest in using the application. The more a person believes that using m-commerce applications will bring good things, the greater the possibility of continual behavioral intention of the users in using them. These findings are similar to those of Raeisi and Meng (2016), Yaghoubi and Brahmani (2010), Celik and Yilmaz (2011), Safeena et al. (2013), arguing that behavior toward behavior influences the interest rate in using a technology.

The results of the data show that the subjective norm in this research did not influence the interest in using m-commerce application to make a purchase with a value of $0.74<1.967$. This t-count results show that hypothesis $3(\mathrm{H} 3)$ is rejected as the subjective norm has no positive effect on the interest in using $\mathrm{m}$-commerce application. The results of this research differ from researches conducted by Safeena et al. (2013), Bhatti (2007), and Rhodes et al. (2006) stating that subjective norms influence the interest rate in using $\mathrm{m}$-commerce applications as well as technology. Referring to the results in Table 17, it is identified that behavior control has a positive effect on interest rate in using $\mathrm{m}$-commerce application to make online purchases with the t-value of $2.16>1.967$.

The t-count results show that hypothesis $4(\mathrm{H} 4)$ is accepted i.e. behavior control positively influences the interest in using m-commerce applications for online purchases. The results of this research are consistent with those of Raeisi and Meng (2016) and Bhatti (2007) arguing that behavior control influences a person on using m-commerce applications. Other researches proposed by Safeena et al. (2013) and Quan et al. (2010) also states that behavior control affects the interest in using a particular technology or information system.

\section{Relationship Pattern of Ease-of-Use on Perceived Usefulness}

Based on Table 2, ease of use has a positive effect on usability of m-commerce application for online purchase with the $t$-value of $18.90>1.967$. This means that the convenient feeling of the users when using 
m-commerce applications will make them conclude that the application is useful for them. The result of the $\mathrm{t}$-count of this research indicates that hypothesis 5 (H5) is accepted i.e. the ease of use positively influences the usefulness of m-commerce applications. The ease of installing the apps up to user-friendly features to do some purchase transaction will make them feel that the application is useful. Management parties that create and provide m-commerce applications must pay attention to this ease of use for m-commerce applications so that the users are attracted. The results of this research are similar to those performed by Gupta (2017), Yaghoubi and Bahmani (2010), Celik and Yilmaz (2011), Suhendro (2009) stating that users will experience greater benefits if they feel ease in using the information system.

\section{The Influential Relationship Pattern of the Ease- of-use and Usefulness on the Attitude of Using M-commerce Application for Online Purchase}

Based on the data results in Table 2, the ease-of-use has a positive effect on the behavior of m-commerce applications usage for online purchases with T-value of $3.98>1.967$. The result of the $t$-count in this research indicates that hypothesis 6 (H6) is accepted, that is the ease of use positively influences the behavior of $\mathrm{m}$-commerce applications. This research is similar to the findings of Gupta (2017), Celik and Yilmaz (2011) and Dias (2012) arguing that the ease of use and benefits of an e-commerce site is an important factor to gain consumer confidence.

The results of data processing in Table 2 show that perceived usefulness positively influences the behavior of m-commerce application usage for online purchase with the $t$-value of $12.93>1.967$. The result of $t$-count in this research shows that hypothesis 7 (H7) is accepted, that is perceived usefulness positively influences the behavior of the use of m-commerce applications. This research is in accordance with the results revealed by Gupta (2017) and Celik and Yilmaz (2011) that usefulness influences the behavior of m-commerce application and information system usage. Quan et al. (2010) also proves that the perception of usefulness has a positive effect on the behavior of mobile service usage. This highlights that when users feel $\mathrm{m}$-commerce applications are easy to use and useful to meet their needs, they will feel confident to continue using the $\mathrm{m}$-commerce applications.
The Relationship Pattern of Security Perception on the Interest Rate in Using M-commerce Application for Online Purchase

The results of the data in Table 2 show that the security perception positively influences the interest in using m-commerce application with a value of $4.98>1.967$. The result of t-count shows that hypothesis 8 (H8) is accepted, that is the perception of security has a positive effect on the interest in using m-commerce application for online purchase. When the security guarantees offered by the $\mathrm{m}$-commerce is sufficient, it enables the $\mathrm{m}$-commerce application users to feel safe when making online purchases. The security factor is crucial in online purchases as sellers and buyers do not meet directly, so it takes a safe system to keep the transaction running smoothly. The results of this research are similar to those of Saleh and Mashhour (2014), Aineah (2016), Park and Kim (2006), and Alwafi and Magnadi (2016) that security will determine the interest rate in using $\mathrm{m}$-commerce applications or information system.

\section{Managerial Implications}

The managerial implication of this research is to give advice to the government in arranging the regulation that regulates e-commerce and m-commerce in Indonesia related to electronic system of security and payment. Improving the quality and scope of internet access needs to be carried out including $4 \mathrm{G}$ network expansion enabling more easily access to $\mathrm{m}$-commerce for the consumers. In addition to the government, this research is also aimed at business actors and SMEs using m-commerce as a means of their business. Business actors who create m-commerce application should make it easy-to-use by creating simple and userfriendly features. Some of the strategies are creating specific campaigns for transactions using $\mathrm{m}$-commerce applications (e.g. discounts, free delivery promotions, etc.), creating applications with a good level of security to maintain the data confidentiality and money transaction guarantees. Thus, convenience feature to make payment must be considered by the company as if the users feel making the payment is difficult then the user may not be interested in using it. Providing good service when making sales to get testimonials can become an effective word of mouth as a marketing strategy. Hotel and accommodation business practitioners make sales by using $\mathrm{m}$-commerce applications to make easier access for consumers. SMEs that have businesses like fashion 
should start selling their products online by creating websites and apps or selling them in e-commerce $/ \mathrm{m}$ commerce existing today.

\section{CONCLUSIONS AND RECOMMENDATION}

\section{Conclusions}

Based on the above objectives and research results, it can be concluded that factors affecting one's interest in using $\mathrm{m}$-commerce applications for online purchase are the behavior of m-commerce application usage, perception of security, behavior control, and perceived usefulness. The subjective norm has no significant effect on interest in using $\mathrm{m}$-commerce applications.

Ease of use and perceived usefulness have a significant effect on behaviors toward m-commerce applications. Such behaviors will ultimately influence the interest in using $\mathrm{m}$-commerce applications for online purchases. The ease of m-commerce applications also has a significant effect on the perceived usefulness when using $\mathrm{m}$-commerce applications to make online purchases.

\section{Recommendations}

The recommendation for further research to complete the limitations of this research is to focus on researching single m-commerce application to thoroughly assess and develop it. In addition, more diverse and sharper variable indicators are also recommendated like the application size when installed, stability of the Internet network, customer service, process of goods delivery, and price and guarantee. Another recommendation would be comparing local and international m-commerce applications.

Recommendation for m-commerce application developers and m-commerce application users for business are obliged to examine its ease-of-use feature. Starting from the installation to the purchase and payment process. The easier the m-commerce application is, the more comfortable the users will feel and continue to use it in the future. Companies can continue to make innovations to create new services that consumers need, so users keep choosing particular $\mathrm{m}$-commerce applications to support them in various things.
Hotel and accommodation business practitioners should start selling by using $\mathrm{m}$-commerce applications to make it easier for consumers to access. The recommendation for business actors or SMEs using m-commerce applications in performing their business is to provide good service when making sales to get testimonials as an effective word of mouth. SMEs that have businesses like fashion should start selling their products online by creating websites and apps or selling them in e-commerce/ m-commerce existing today. SME actors also need to learn to do promotions to attract consumers to buy in their online store, such as discounts and free delivery.

\section{REFERENCES}

[APJII] Asosiasi Penyelenggara Jasa Internet Indonesia. 2016. Jumlah pengguna Internet Indonesia. www.apjii.or.id [22 April 2017].

Aineah BN. 2016. Factors influencing online purchasing intention among college students in Nairobi City [theses]. Nairobi: United States International University.

Ajzen I. 1991. Theory of planned behavior and human decision process. Organizational Behaviour and Human Decision Processes 50(2): 179-211. https://doi.org/10.1016/0749-5978(91)90020-T.

Alwafi F, Magnadi RH. 2016. Pengaruh persepsi keamanan, kemudahan bertransaksi, kepercayaan terhadap toko dan pengalaman berbelanja terhadap minat beli secara online pada situs jual beli tokopedia.com. Diponegoro Journal of Management 5(2): 1-15.

Bhatti T. 2007. Exploring factors influencing the adoption of mobile commerce. Journal of Internet Banking and Commerce 12(3): 1-13.

Celik HE, Yilmaz V. 2011. Extending the technology acceptance model for adoption of e-shopping by consumer in Turkey. Journal of Electronic Research 12(2): 152-164.

Chaffey D. 2007. E-Business and E-commerce Management, 3rd Edition. Harlow: Pearson Education Limited.

Davis FD. 1989. Perceived usefulness, perceived ease of use, and user acceptance of information technology. MIS Quarterly 13(3): 319-340. https://doi.org/10.2307/249008.

Dias A. 2012. Analisis kepercayaan konsumen terhadap situs jual beli tokobagus.com: antecedents dan outcome [tesis]. Depok: Universitas Indonesia. 
Engel JF, Blackwell

1995. Perilaku

RD, Miniard PW.

konsumen. Jakarta:

Binarupa Aksara.

Fusilier M, Durlabhji S. 2005. An exploration of student internet use in india the technology acceptance model and the theory of planned behaviour. Campus-Wide I $n$ for $m$ a $t$ i o $n$ Systems 22(4): 233-246.http://dx.doi. org/10.1108/10650740510617539.

Gupta M. 2017. Revised technology acceptance model framework for m-commerce adoption. International Journal of Social, Behavioral, Educational, Economic, Business and Industrial Engineering 11(7): 1749-1753.

Hair JF, Anderson RE, Tatham RL, Black WC. 1995. Multivariate Data Analysis with Reading. 4th Ed. New Jersey: Prentice Hall, Inc.

Javadi MHM, Dolatabadi HR, Nourbakhsh M, Poursaeedi A, Asadollahi AR. 2012. An analysis of factors affecting on online shopping behavior of consumers. International Journal of Marketing Studies 4(5): 81-98.

Jogiyanto H. 2007. Model Kesuksesan Sistem Teknologi Informasi. Yogyakarta: Andi Press.

Kotler P, Keller KL. 2007. Manajemen Pemasaran, Edisi 12, Jilid 1. Jakarta: PT. Indeks.

Leng GS. 2011. An exploration of social networking sites (sns) adoption in malaysia using technology acceptance model (TAM), theory of planned behavior (TPB) and intrinsic motivation. Journal of Internet Banking and Commerce 16(2): 1-27.

Park CH, Kim YG. 2006. The effect of information satisfaction and relational benefit on consumers online site commitments. Journal of Electronic Commerce in Organizations 4(1): 70-90.

Peterson DK. 2012. The colbert bump and the facebook follow-through for generation snark: a test and extention of the ajzen's theory of planned behavior for 2012. Journal of Management Research 4(3): 43-65. https://doi.org/10.5296/ jmr.v4i3.1597.

Quan S, Hao C, Jianxin Y. 2010. Factors influencing the adoption of mobile service in China: an integration of TAM. Journal of Computers 5(5): 799-806.
Raeisi S, Meng L. 2016. Factors influencing to $\mathrm{m}$-commerceadoption in China. The International Journal of Business \& Management 4(3): 372 384.

Safeena R, Date H, Hundewale N, Kammani A. 2013. Combination of TAM and TPB in internet banking adoption. International Journal of Computer Theory and Engineering 5(1): 146-150. https:// doi.org/10.7763/IJCTE.2013.V5.665.

Saleh ZI, Mashhour A. 2014. Consumer attitude towards $\mathrm{m}$-commerce: the perceived level of security and the role of trust. Journal of Emerging Trends in Computing and Information Sciences 5(2): 111117.

Sekaran U. 2011. Metodologi Penelitian untuk Bisnis, edisi 4. Jakarta: Salemba Empat.

Suhendro. 2009. Pengaruh perceived usefulness dan perceived ease of use dalam penggunaan sistem informasi keuangan daerah [tesis]. Surakarta: Universitas Sebelas Maret.

Venkatesh V, Davis FD. 2000. A theoretical extension of the technology acceptance model: four longitudinal field studies. Journal of Management Science 46 (2): 186-204. https://doi.org/10.1287/ mnsc.46.2.186.11926.

Wakefield RL, Whitten D. 2006. Mobile computing: a user study on hedonic/utilitarian mobile device usage. European Journal of Information Systems 15(3): 292-300. https://doi.org/10.1057/ palgrave.ejis.3000619.

Yaghoubi NM, Bahmani E. 2010. Factors affecting the adoption of online banking an integration of technology acceptance model and theory of planned behavior. International Journal of Business and Management 5(9): 159-165. https://doi.org/10.5539/ijbm.v5n9p159.

Yaseen SG, Zayed S. 2010. Exploring Determinants in Deploying Mobile Commerce Technology: Amman Stock Exchange. UK Academy for Information Systems Conference Proceedings 2010; 2010 Maret 23; United Kingdom. Inggris: AIS Electronic Library (AISeL). hlm 1-18; [diunduh 2017 Mei 5]. Tersedia pada: http:// aisel.aisnet.org/ukais2010/5.

Yuswohady. 2017. Welcome leisure economy. http:// www.yuswohady.com/2017/10/28/welcomeleisure-economy/ [ 2 Desember 2017]. 